\title{
Selection for reinforcement versus selection for signals of quality and attractiveness
}

\author{
Geoffrey E. Hill \\ Geoffrey E. Hill, (ghill@acesag.auburn.edu), Department of Biological Sciences, 331 Funchess Hall, Auburn \\ University, Auburn, AL, USA 36849-5414
}

As the foundation for an essay on why hybridization occurs in ornamented birds, Martin (2015) presents a paradox. Birds-of-Paradise are widely recognized as the most highly ornamented family of birds in the world (Frith et al. 1998), and yet species in this family hybridize more frequently than do species in most other families of birds (Martin 2015). Hybridization in Birdsof-Paradise is a paradox not simply because the species in this family have such fantastic ornamentation; rather, hybridization is a paradox in this family of birds because the colors, patterns, shapes, and lengths of feathers, not to mention the behaviors that accompany the plumes, are extremely divergent among species (Firth and Beehler 1998). Thus, it seems absurd to propose that a choosing female could confuse a male King Bird-of-Paradise (Cicinnurus regius) resplendent in crimson plumage with a male Magnificent Bird-ofParadise with its brilliant green, yellow, and blue coloration. Species recognition should be trivial, and hybridization avoided in such species. Indeed, it is proposed that the imperative to avoid hybrid mating is the selective force that drove the divergence in the ornamentation of birds and other animals (Mayr 1963, Wallace 1889). And yet, King Birds-of-Paradise and Magnificent Birdsof-Paradise occasionally hybridize (Firth and Beehler 1998: 507).

Martin (2015) proposes some plausible and certainly very insightful ideas to explain the relatively high rates of hybridization among ornamented species of birds such as species in family Paradisaeidae. He points out that if ornaments arise as signals of species identity that are assessed by females to avoid pairing outside of species boundaries then selection for such traits may be strongest where the possibility of hybridization is greatest. Conversely, species with little risk of hybrid pairing are under little selection to diverge in ornamentation. Hence, Martin argues that if reinforcement of species boundaries is a selective force in ornament evolution then we should see higher rates of hybridization where ornamentation is the most elaborate, as in the Birds-ofParadise, because it is in such species that the propensity for hybridization is highest.

Martin acknowledges that females might choose ornamentation for reasons other than identifying males of the correct species, but I think that he gives too little consideration to the complications that arise when there is strong selection on females to assess aspects of potential mates beyond their species identity. Females potentially make three key assessments in choosing among prospective mates: they assess the population to which the male belongs, they assess the quality of the male, and they assess the sexiness of the male (Hill 2015, Hill and Johnson 2013). These three distinct assessments form the basis for the three prominent models of sexual selection: species recognition; indicator trait, and run-away. The species recognition model, which Martin refers to as "reinforcement" following convention in the evolutionary literature (Hudson and Price 2014, Pfennig and Rice 2014), proposes ornaments arise as unambig-uous signals of species identity that enable females to mate within species boundaries (Mendelson and Shaw 2012, Ritchie 2007, Ryan and Rand 1993, Wallace 1889). In contrast, the indicator trait hypothesis pro-poses that ornamental traits signal the quality of prospective mates enabling choosing females to identify those males with the best resources or the best genes to pass on to offspring (Andersson 1986, Grafen 1990, Hamilton and Zuk 1982, Kodric-Brown and Brown 1984, Zahavi 1975, 1977). Finally, the runaway hypothesis (also called the 
Fisherian model or the Lande-Kirpatrick model) proposes that ornamental traits are attractive for their own sake (Prum 2010, Weather-head and Robertson 1979). By this latter model, males that possess the ornament are inherently attractive and hence have increased reproductive success relative to males lacking the ornament through access to more mates. Females that choose such sexy males gain by producing attractive sons (Kirkpatrick 1987, Kirkpatrick and Ryan 1991, Lande 1981). A consideration of these alternative models is essential for an understanding of the evolution of ornamentation and the persistence of hybridization in ornamented animals.

Perhaps the key implicit prediction in Martin's essay is that stronger selection for premating isolation leads to the evolution of more elaborate ornamentation. I cannot find this specific prediction in the literature on reinforcement (e.g. Kirkpatrick and Ravigné 2002, Price 2007, Servedio and Noor 2003), and I do not accept the prediction. To the contrary, the more complicated a suite of ornaments becomes, the more complex that female recognition systems will need to be to respond appropriately to con- and hetero-specifics and the greater will be the likelihood of mistakes (Hudson and Price 2014). Signals of species identity should work best when they are simple and unambiguous (Dale 2006, Maynard Smith 1991). Moreover, selection for premating isolation will act primarily on the recognition systems of females, not male ornaments (Hudson and Price 2014). Increasing the complexity of ornaments should lead to a greater rate of error in mate choice as occurs in Birds-of-Paradise and other highly ornamented animals and hence would not arise through selection for premating isolation.

In my opinion, Martin provides a key insight in pointing out that extreme ornament elaboration is often associated with lek mating systems and a lack of parental care (Ligon 1999). With no exposure to the male parent during development, birds in lek mating systems lack the opportunity for imprinting to reinforce innate mating preferences (Clayton 1990, Irwin and Price 1999), and are more prone to errors in choosing mates. In this way, lack of parental care would also cause the most ornamented species to have the relatively high rates of hybridization.

If ornament elaboration gives rise to costs in the form of increased rates of hybridization then why does elaboration occur? The most likely answer is that trait elaboration is driven by selection for indicator traits or through a runaway process (Andersson and Simmons 2006, Kirkpatrick Mark and Ryan 1991). Like signals of species identity, signals of male quality work best if they are simple and easy to assess (Dale 2006, Hill 2002, Kodric-Brown and Brown 1984). Potentially, elaboration may be needed to insure honesty in indicator traits by increasing the cost of the display (Badyaev
2004, Hill 1994), but there is little evidence that more elaborate traits are more costly. I think the more likely explanation for elaboration and dramatic divergence in appearance among taxa is that that signals of species identity are elaborated through a runaway process. The runaway model of sexual selection is the only current theory that predicts rapid elaboration of ornamentation as is typified by Birds-of-Paradise (Prum 2010). Interestingly, models suggest that trait elaboration via a runaway process will directly oppose selection for reinforcement, causing a breakdown of isolating mechanisms (Servedio and Bürger 2014). This model predicts that the highest rates of hybridization will occur in taxa subject to the strongest runaway sexual selection. It potentially explains the patterns presented by Martin.

In conclusion, discussions of the role of ornamentation in reinforcement of the isolation of gene pools generally have not adequately considered the diverse selection that can underlie ornament evolution. Traits that arise through selection for signals of quality or for aesthetic beauty might also serve as recognition signals. In general, however, signals of quality will be too variable to serve as reliable signals of species identity, and trait elaboration through a runaway process can confound female recognition systems. Unless different signals that are conveyed by different ornaments are considered, there is little hope of understanding patterns related to ornamentation like hybridization in Birds-ofParadise.

\section{References}

Andersson, M. 1986. Evolution of condition-dependent sex ornaments and mating preferences: sexual selection based on viability differences. Evolution 40:804-816. CrossRef

Andersson, M. and L.W. Simmons. 2006. Sexual selection and mate choice. Trends in Ecology \& Evolution 21:296-302. CrossRef

Badyaev, A.V. 2004. Developmental perspective on the evolution of sexual ornaments. Evolutionary Ecology Research 6:975-991.

Clayton, D.H. 1990. Mate choice in experimentally parasitized Rock Doves: Lousy males lose. American Zoologist 30:251-262. CrossRef

Dale, J. 2006. Intraspecific variation in bird colors in Hill GE, McGraw KJ, eds. Bird Coloration, Volume 2. Function and Evolution. Cambridge, MA: Harvard University Press.

Frith, C.B., McP, B., Cooper, W.T., and M. McGuire. 1998. The birds of paradise: Paradisaeidae. Oxford University Press New York.

Grafen, A. 1990. Sexual selection unhandicapped by the Fisher process. Journal of Theoretical Biology 144:473-516. $\underline{\text { CrossRef }}$ 
Hamilton, W.D., and M. Zuk. 1982. Heritable true fitness and bright birds: a role for parasites? Science 218:384-386. CrossRef

Hill, G.E. 1994. Trait elaboration via adaptive mate choice: sexual conflict in the evolution of signals of male quality. Ethology, Ecology and Evolution 6:351370. CrossRef

Hill, G.E. 2002. A red bird in a brown bag: the function and evolution of ornamental plumage coloration in the House Finch. Oxford University Press. CrossRef

Hill, G.E., 2015. Sexiness, individual condition, and species identity: the information signaled by ornaments and assessed by choosing females. Evolutionary Biology, online. $\underline{\text { CrossRef }}$

Hill, G.E., and J.D. Johnson. 2013. The mitonuclear compatibility hypothesis of sexual selection. Proceedings of the Royal Society B-Biological Sciences 280. CrossRef

Hudson, E.J., and T.D. Price. 2014. Pervasive reinforcement and the role of sexual selection in biological speciation. Journal of Heredity 105:821833. CrossRef

Irwin, D.E., and T. Price. 1999. Sexual imprinting, learning and speciation. Heredity 82:347-354. CrossRef

Kirkpatrick, M. 1987. Sexual selection by female choice in polygynous mammals. Annual Review of Ecology, Evolution, and Systematics 18: 43-70. CrossRef

Kirkpatrick, M., and V. Ravigné. 2002. Speciation by natural and sexual selection: models and experiments. The American Naturalist 159:S22-S35. CrossRef

Kirkpatrick, M., and M.J. Ryan. 1991. The evolution of mating preferences and the paradox of the lek. Nature 350:33-38. CrossRef

Kodric-Brown, A., and J.H. Brown. 1984. Truth in advertising: the kinds of traits favored by sexual selection. American Naturalist 124:309-323. CrossRef

Lande, R. 1981. Models of speciation by sexual selection on polygenic traits. Proceedings of the National Academy of Sciences USA 78:6:3721-3725. CrossRef

Ligon, J.D. 1999. The evolution of avian breeding systems. Oxford University Press.

Martin, P.R. 2015. The paradox of the Birds-ofParadise: persistent hybridization as a signature of historical reinforcement. Ideas in Ecology and Evolution 8: 58-66. CrossRef

Maynard Smith, J. 1991. Theories of Sexual Selection. Trends in Ecology and Evolution 6:146-151. CrossRef

Mayr, E. 1963. Animal Species and Evolution. Harvard University Press. CrossRef

Mendelson, T.C., and K.L. Shaw. 2012. The (mis)concept of species recognition. Trends in Ecology \& Evolution 27:421-427. CrossRef
Pfennig, K.S., and A.M. Rice. 2014. Reinforcement generates reproductive isolation between neighbouring conspecific populations of spadefoot toads. Proceedings of the Royal Society B: Biological Sciences 281:20140949. CrossRef

Price, T. 2007. Speciation in Birds. Roberts and Company Publishers.

Prum, R.O. 2010. The Lande-Kirkpatrick mechanism is the null model of evolution by intersexual selection: Implications for meaning, honesty, and design in intersexual signals. Evolution 64:3085-3100. CrossRef

Ritchie, M.G. 2007. Sexual selection and speciation. Annual Review of Ecology Evolution and Systematics 38:79-102. CrossRef

Ryan, M.J., and A.S. Rand. 1993. Species recognition and sexual selection as a unitary problem in animal communication. Evolution 47:647-657. CrossRef

Servedio M.R., and R. Bürger. 2014. The counterintuitive role of sexual selection in species maintenance and speciation. Proceedings of the National Academy of Sciences 111:8113-8118. CrossRef

Servedio, M.R., and M.A. Noor. 2003. The role of reinforcement in speciation: theory and data. Annual Review of Ecology, Evolution, and Systematics:339364. CrossRef

Wallace, A.R. 1889. Darwinism. Macmillian.

Weatherhead, P.J., and R.J. Robertson. 1979. Offspring quality and the polygyny threshold: the "sexy son" hypothesis. American Naturalist 113:201-208. CrossRef

Zahavi, A. 1975. Mate selection-a selection for a handicap. Journal of Theoretical Biology 53:205-214. CrossRef

Zahavi, A. 1977. The cost of honesty (further remarks on the Handicap Principle). Journal of Theoretical Biology 67:603-605. CrossRef 